\title{
Empowering Women Through Mother Groups A Case Study of Hanshposha Aama Samuha, Itahari- 20, Sunsari
}

\author{
Tanka Mani Poudel \\ Lecturer \\ Department of Sociology, Mahendra Multiple Campus, Dharan, Tribhuvan University, Nepal \\ tpoude1059@gmail.com
}

DOI: https://doi.org/10.3126/dristikon.v11i1.39158

\begin{abstract}
Empowering of women has become the major aspect of growth of the financial system of a country. It is basically the manner of enhancement of social, economic, cultural and political standing of women, the conventionally disadvantaged, neglected ones, in the society. This study has been carried out in Itahari sub-metropolitan, Sunsari district. The central theme of this study is to assess the role of Aama Samuha for empowerment of women and social development. This study entertains both primary as well as secondary data. The primary data have been collected from the field through survey Questionnaire, semi-structure interview, and observation. The interview was focused mainly on empowerment of women through mothers group, problems faced by the members of MG, while working in the group, attitude of males toward mothers group and role of mothers group in social development. Mothers Group of Hanshposha has contributed much in social development like cleaning trails, making road, plantation on public area, financial support to local school, and construction of building for temples, financial support to helpless people and poor people and maintaining peace and harmony in the community.
\end{abstract}

Keywords: women, gender, empowerment, Aama Samuha

\section{Introduction}

Empowerment has become one of the most elastic of international development's many buzzwords (Batliwala, 2007; Cornwall \& Eade, 2011). Feminists have long argued that empowerment is not something that can be done to or for women (Rowlands, 1997; Kabeer, 1999; Batliwala, 2007). Empowerment of women is basically the manner of enhancement of social, economic, cultural and political standing of women, the conventionally disadvantaged, neglected ones, in the society. Batliwala (1994) argued that the growing talk of women's empowerment was in danger of losing the concept's transformative edge. She called for a more precise understanding of both power and empowerment. Defining power 'as control over material assets, intellectual resources and ideology' (p. 129), she cast empowerment as 'the process of challenging existing power relations, and of gaining greater control over the sources 
of power' (p. 130). Empowerment is treated as a destination reached through development's equivalent of motorways: programmes rolled out over any terrain. But in the process, pathways women are travelling in their own individual or collective journeys of empowerment remain hidden (Cornwall, 2016). Women empowerment is an active multi-dimensional process to enable them to realize their identity and power in all spheres of life through greater self-reliance and internal strength (Narang, 2012). Women empowerment requires the improvement in every aspect of their life. These aspects include social, cultural, economic, legal and political involvement and participation. These participations are possible only when the women have access to education, health and other social security such as legal and administrative protection. Hence, women empowerment is the process of getting women uplifted from miserable, illiterate and deprived situation to the situation with own decision making power.

Empowerment is an important issue of public concern; it can have an immense and intense impact, especially on women's lives and, in general, on the society as a whole. It would also be unjust to keep such a large section of the population away from decision making and operational processes. It is not only the issue of being a larger population but essentially of having a vital role in every walk of life, including being the key agent to transfer culture and tradition to the new generation (Pandey, 2018, p.2). Economic self-reliance is one of the main pillars of women empowerment. It is one of the important elements to improve women's participation in social and political activities. But in the Napalm context, women's participation in informal economic activities is very high. It is seen that only 26.2 per cent women employees are in formal employment and earning only 59.3 per cent of men's average earning (Government of Nepal, 2008). The Central Bureau of Statistics (CBS) shows that female ownership in the fixed asset as house and land is 19.71 per cent, which was 9.11 per cent in 2001 (The Central Bureau of Statics, 2011). The Government of Nepal (GoN) ensures women's participation in all spheres of life, which is manifested in the agendas of political parties as well (Government of Nepal, 2015). Nepalese women are one of the most socially and culturally vulnerable groups exposed to discriminations at home due to patriarchal structure.

Sara Longwe argues that much of the development literature examines to what extent equality between women and men has been achieved according to the conventional sectors of economy and society: equality in education, employment, and so on. The Longwe Framework centers on the concept of five 'levels of equality', (Control, Participation, Conscientisation, Access and Welfare) which indicate the extent to which women are equal with men, and have achieved empowerment. The levels of equality can be used to assess the likelihood of particular development interventions promoting equality and women's empowerment (March et al., 1999). The concept of empowerment has a long history in social change work. Feminist consciousness-raising and collective action informed early applications in international development in the 1970s. Women's empowerment came to be articulated in the 1980s and 
1990s as a radical approach concerned with transforming power relations in favors of women's rights and greater equality between women and men (Batliwala, 1993, 2007). Empowerment is the process by which women gain power and control over their own lives and acquire the ability to make strategic choice. It can be defined in different levels as an individual, group, and societal or community. The empowerment processes in the different levels are interconnected and mutually reinforcing ( Megharaja, 2014). Hence, empowerment is multidimensional in nature. With regard to empowering women through the socio-economic process, having their appropriate participation in the different socio-economic mechanism with a capacity of selfdetermination and standing with self-esteem.

Mother's Group is universalized traditional volunteer women's organization in Nepal initiated from 1980s in rural Nepal. In the initial stage those groups were flourished in Gurung and Magar communities where most of the male members were out of home and joined army in Nepal, India and UK. Those women were organized for cultural social, religious matters and started to convince meetings, discussions and small programs initiated by various NonGovernmental Organizations (NGO) in rural Nepal since 1980s. ( Gurung,1998) . Mother's group is perhaps one of the most universalized traditional voluntary organizations in Nepal. It first started with the Gurung's of western Nepal. As most of the Gurung men used to join in the British Army. And more recently, in Indian Army for the last two decades. Gurung women formed mother's group to sing, dance and organize cultural activities in the evening one of the most interesting activities they performs is to welcome returnee Lahures and guest visitors. The lahures (returnee British or India army men) and guest visitors donate money to the Aama Samuha. Aama Samuha usually organizes singing and dancing programs in the evening and collected money is used to build trials temples etc. Many NGOs/INGOs have formed and promoted Aama Samuha across the country among different caste and ethnic groups. The Aama Sumuha of Bahun-chettri caste have very aggressively raised anti-alcohol movement in the villages. Mother's Group (MG) started form Gurung community of Gandaki Zone Annapurna conservation Area project (ACAP) has important role to begin MG (Gurung, 1998). Sharma (1997) says that mothers' groups, historically, were exclusive to the Gurung community. But in recent years, they have evolved as an organization of all castes and ethnic groups.

Literature has shown that MGs are evolving and modifying their objectives and goals according to the changing local needs. Initially they started their contribution with community and infrastructure development but now they focus more on social reforms such as discouraging alcoholism, gambling and other social evils (Sharma, 1997). In rural villages of Nepal, women have started empowering themselves through the formation of their own groups -Aama Samuha. Such groups seem to be playing important role for women's empowerment. Establishment of mothers Group at local level has at least united women for their common goal 
of increasing their participation in community development. However, such groups are not getting proper support and guidance from the government and community itself. This study has been carried out to answer the following research questions:

- How women are empowering through Mother Group in the study area?

- What is the role of Mother Group for social development in the study area?

- Is there positive attitude of male towards such groups?

\section{Materials and Methods}

This study is based on urban area of Eastern Development Region. Itahari is a multicultural town of Eastern Nepal. It lies on Sunsari District in Koshi Zone. The study area was an appropriate place for the study of the role of mothers group for empowerment of women and social development because Hanshposha mothers group has been working for more, than 15 years there. Hanshposha mothers group was the universe of this study. It has 300 women members, who are directly involved in different activities conducted by MG. Therefore, the total number 300 were universe of the study, 90 women's (30\%) were selected by adopting simple random sampling for the study. Furthermore, researcher has selected 10 males especially fathers who were not directly involved in such groups on the basis on purposive sampling method. I have used the both exploratory and descriptive research design. Descriptive design has been adopted to describe the prevalent condition of women in the research area while exploratory has been conducted to the role of women empowerment and social development through mothers group in the research area.

This study entertains both primary as well as secondary data. The primary data have been collected from the field through survey Questionnaire, semi-structure interview, and observation. The interview was focused mainly on empowerment of women through mothers group, problems faced by the members of MG, while working in the group, attitude of both males toward mothers group and role of mothers group in social development. The data were analyzed in qualitative and quantitative ways. Collected data was processed and tabulated during the completion of the study. Both qualitative and quantitative data were presented and interpreted.

\section{Results and Discussion}

MG initiated by Gurung women as a self-help organization in the past, has become popular women organization all over the country for women development. Mothers' Groups are recognized as a non-political group which has played a significant role for the empowerment and mobilization of women at grassroots.

\section{Women Empowerment Programme}


Hanshposha mothers group has conducted different types of training and development programme. Most of the trainings are based on Tailoring, Beautician and literacy program. During the training programs different groups interact with each other and find out the ways of prospering their activities. Since establishment, Hanshposha Mothers Group has been launching its program actively in the study area. Moreover, it has been launching various programs for financial, social and political empowerment of women. In addition, various saving and credit group has been established and launching various saving and credit program by this mothers groups saving and credit group for the fact that availability of capital has been considered to be a fundamental pre-requisite for meeting resources required for promoting investment in income generating activities. There are 25 saving and credit group (only mothers) initiated by MG.

\section{Case 1: Training Helps to Make Success}

I am Rita Katwal. I was born in the middle class family in the remote area of Sindhuli. I completed SLC from a government school. When I entered in Mother Group with the help of friends, I got opportunity to utilize the desires and skills that I had since my childhood. I got the training of three-months tailoring and by which I have become able to open a tailor shop. I have bought a machine and kept other three machines provided to me by the group and providing the training of tailoring to 14 women. After getting involved in Mother Group, my abilities have increased and I've participated in various social activities. Despite the absence of my husband I have been able to manage the household and provide the education to children. I consider myself to be a successful women and this credit goes to the Mother Group.

Aama Saving and Credit Co-operative Ltd. For the economic empowerment of women, Hanshposha Mothers Group has established a micro-finance called "Aama Saving and Credit Co-operative $\mathrm{Ltd}^{1}$." and conducting it successfully since Srawan of 2066 B.S. The ASAC Co-Ltd. has 300 general members out of which an executive committee is formed consisting of ten members The SAC Co-Ltd. has its own organizational laws, rules and policy to run the organization effectively.

\section{Case 2: Support of Man is Essential in Women's Life}

It's me Pabitra Ghimire. I consider myself as a educated women. After getting marriage, despite I had to felling that I possessed the ability to do something I could not do it due to domestic circumstance. But, I could be the member of Mother Group with the advice and support of my husband in 2058 B.S. Along with the involvement in the group I committed myself to prosper it but I had to face the physical as well as mental torture while raising the voice against alcoholism and gambling that often occur in the village. However, the Mother 
Group could march ahead by solving such problems and hardships. I have participated in almost all the trainings conducted by the group. I have been working as a treasurer of the group as my contribution has been acknowledged. Furthermore, I have been working as a treasurer in the Aama Saving and Credit Co-operative limited established by Mother Group. The credit of my success goes to my own honesty and sincerity.

\section{Activities Related to Social Development}

The activities of MGs are implemented for community development. Mothers Group of Hanshposha has contributed as much in social development sectors. Mothers group of Hanshposha has been launching programs against gambling, drinking alcohol, road construction, sanitation, public awareness, physical and financial help in construction of temple and public school, programs for forestations and controlling deforestation, established of child development center, celebration of programs like. "Red clothes for widow" As a result of this program, 60 percent widow, wearing red color clothes and ending of caste discrimination MG celebration of "Group Vai Tika" on Tihar, 100 brothers were involved from different caste. Similarly, mothers group had initiated door-to-door campaign on making local people (especially Mushar and Tharu community) aware of good sanitation around home and building toilet, as a result, nearly 90 percent of the toilet less family built temporary toilets supporting the good sanitation program initiated by Hanshposha mothers' group. MG has carried out social activities like cleaning trails, plantation of tree in public area, financial support to local school and local temple for constructing new building, helping poor and helpless people, maintaining peace and harmony in the community.

\section{Case 3: Disaster- Ridden People Should be Helped}

The flood in Koshi in 2065/5/2 B.S over flooded the scores of house nearby the river. Almost all Nepalese citizens of home and abroad readily helped those disaster-ridden people, right after the calamities. The mothers group of the VDC, collected some amount of money to offer the help to those people. They formulated a group of seventy members to have the observation to provide the help to those people and they provided the things and food staffs. (Cash amount Rs. 8, 000, Beaten Rice: $50 \mathrm{Kg}$, Dishes: 20 Pcs, Bhuja :50 Kg, Biscuits :15 C/S, Slipper and shoes : 20 pairs ).

\section{Attitude of Males Towards MG}

Altogether seven fathers and three male social leaders were interviewed to find out their attitude towards mothers group operating in their community. MG was guided by the social leaders of the society though their guidance was not regular and sufficient. In response to how they regarded the mothers' effort to empower themselves through MG, they said that it was positive change in the attitude of mothers, the MG was self initiated. Fathers were found to have seen some noticeable changes in their wives after being members of MG. 


\section{Case 4: Opinion Provided by Mr. Ram Bahadur Ghimire}

I had realized much more differences in my wife's behavior after her involvement in MG. Before getting involved in MG, she was also limited within household activities although she had some probability of doing something if she got an opportunity. Later, her desires were fulfilled through MG. She fostered her inner capability to speak out clearly and with confidence in front of mass. She developed social feelings. She makes decision on sole household activities that arenot only reasonable but also rigid. Now she has also represented many social institutions like community forest user's group, Aama Saving and Credit Group, school management committee etc. She has established her own prestigious position in the society as a result of her involvement in MG.

The social leaders said that the representations of women in social institutions have been raised since the emergence of mothers groups. Mothers were representing social organization like school management committee, community forestry committee, temple construction committee, drinking water supply committee after their involvement in MG, they have started presenting themselves consciously in the programs like parents' day in schools, annual anniversary programs and open discussion programs on public issues etc.

\section{Problems of Mothers' Group}

Mothers Group formation in Hanshposha, itself is a big task by getting a likeminded people. Mothers' group's members encouragingly perform their activity. As the group activities pick up the struggle for existence among the members sometimes mothers in the Group violate the rules and regulations of the group. Few members in a group are non-co-operative. The study is made deeper in to the problems faced by the Hanshposha mothers group presented in the table.

\section{Table 1}

\section{Problems Faced by MG Members}

\begin{tabular}{lrr}
\hline \multicolumn{1}{c}{ Item } & Total & Percentage (\%) \\
\hline Lack of Training & 35 & 39 \\
Problem in getting the loan released in time & 20 & 22 \\
Lack of common work shed & 15 & 17 \\
Non-co-operation among the group members & 12 & 13 \\
Non-availability of the group member & 5 & 6 \\
Amount sanctioned for group is insufficient & 3 & 3 \\
Total & 90 & 100 \\
\hline
\end{tabular}

Note. The data received from Field Survey 2020.

The table has showed that there is a lacking of training among 39 percent mothers whereas 22 percent mothers are suffering with a problem of getting the loan released in time 17 
percent mothers are not having common workshed, 12 percent mothers are not co-operating among the group members and 6 percent mothers are not available to groups. And for 3 percent mothers the amount sanctioned is not sufficient. The information indicates that women members are not having sufficient training facilities earlier and slowly they are getting trained.

\section{The Problems Faced by Mothers Group Members While Working in MG}

Lack of Sufficient Guidance From Social Leaders. According to some of the members of the MG of Hanshposha, it has been found that the social leaders have not given much attention to MG. They said that the social leaders regarded MG as exclusively women group; so they wanted mothers to handle their groups themselves. They do not organize any programs for promoting mothers. Thus, mothers have limited themselves with in the own groups.

Lack of Networking with Other Formal Organization. The researcher has found that the mothers group operating in Hanshposha, were running by themselves. There is no formal link among MGs operating in Hanshposha. There are many women related organization working in Hanshposha but most of the mothers group do not have formal organizational link.

Internal Conflict. According to the interviewed MG members internal conflict was the main problem faced by MG in Hanshposha. It was found that due to internal conflict arises among MG members because of lack of transparency in financial accounting and unsystematic way of fund rotation system. The conflict is still going on between the chairperson and the secretary.

Limited Financial Sources. Researcher has found that the main source of fund of MG operating in Hanshposha was the monthly saving of the MG members. Now, they are feeling financial problem for conducting program.

Influence Over the Group by few Dominant Mothers. The general members of MG of Hanshposha, were found dissatisfied from their group because of control over the group by a few dominant mothers.

Low Level of Educational Attainment. The educational background of the MG members has shown that most of mothers are were just literate, so they cannot actively participate in various social activities and income generating activities because of the lack of education.

\section{Case 5: Where There is Interest we can do Anything What we Want}

I am Urmila Shrestha. I have not taken any formal education. I have become literate after getting the adult education provided by the mother group. It was very difficult for me to involve in the group as my husband was a drunkard and he tortured me a lot physically. I had the desire to be the member of the group when I heard about it from the neighbor women and I had asked 
for the suggestion with my husband too. But, instead of suggestion. I was beaten twice for this issue. Nevertheless, with my courage and the support of other women of the group. I was able to involve the group in 2059 B.S. I participated in various social activities and training of the group and I was able to develop my skills and abilities. I was able to buy a cow taking the loan of Rs. 10,000 from the group. Now, I have been managing the family by selling the milk, and it has been supporting for the education of my children. I have felt the positive change in my husband after seeing my success. Now, my husband has also run a biscuit factory. We take every decision of the family together. Thus, the credit of my success goes to Mother Group.

\section{Impact Analysis of Mothers' Group}

Change in Social Status. According to them, they have been successful, to greater extent, to change the traditional concept prevailing in the society that women can't do anything in social development. But that concept has been changed when mothers started performing social activities. Mothers have also cultivated social feeling. Before involving in the MG, their social relationship and contacts were limited within household. But After getting involved in the MG, their social relationship, level of contact has extended.

Involvement in Social Activities. After getting involved in the MG, they were interested to join other social institution and program. In response to the question whether they got involved in social activities or not, 75 percent of mothers responded that they had been involved in social activities representing social institutions like, forest user's group, school management committee, temple management committee, road construction committee and drinking water supply management committee, Nagarik sudar committee, and other local institution like, local government, polices, NGO/INGO and health related organization etc.

Decision-Making Capabilities. Decision-making capabilities of members were found to be highly depended upon the family background of the members. The mothers from nuclear family were found to have much more opportunities to make decisions than the members from joint family 84 percent (76 mothers), of the members were from nuclear family. Among them, 55 percent (50 mothers) of the members made decisions jointly with their husbands except in kitchen maintenance like making decision on schooling of their children, buying clothes, etc. But the members from joint family, they were found to be hardly involved in decision-making process. Among 16 percent (14 mothers) members, only 20 percent ( 3 mothers) members said that they are also consulted making decisions on major issues like buying, selling house, land etc.

After getting involved in MG, they had felt significant changes in their decisionmaking. Nearly 70 percent (63 mothers) said that there has been change in the pattern to decision making. They said that before joining the groups, they used to limit their decision only in the kitchen maintenance but, after getting involved in MG, they analyzed the issue logically 
and sometimes they disagreed the decisions made by others and gave their own decision. They also said that there is change in their self-confidence, behavior, knowledge, communicating skill etc. after getting involved in MG. By getting the training and link with different people mother got more knowledge and increased the power of leadership, that helped them to make decision on their risk either that were on household or on public issues.

Change in Attitude of Family Members and Neighbors. Involvement in mothers group and in income generating activities and social activities had changed their attitude of family members and their neighbor. Their occupation, public life, saving, mobility knowledge and confidence had changed their family members and neighbor's concepts towards them. It was found that 70 percent ( 63 mothers) of the members have felt change in the attitude of family members towards them. They said that due to the organizational practice in MG, training, access to new knowledge and skill they have become more confident to talk on any issues. They started getting themselves involved in household decision making. Which has made the family members (especially husband) to realize their role in the family. Among them 33 percent (30 mothers) have felt change in the attitude of their neighbor because of the increment in their confidence level and involvement in social activities. But 20 percent (18 mothers) members didnot feel any changes of their family members and neighbors towards them because of their low access to the opportunities like training, social activities etc.

\section{Case 6: If Women get Opportunity They can do Anything That man can not do}

My name is puja magar. I am 38 years old. I was born in an extremely poor family in Dharan. I had studied upto class 8 in Shree Sahid Smiriti Secondary school in Dharan but couldn't continue my study due to the lack of economic support. I got married to Vijaya Magar of Hanshposha in 2056 B.S. I have two children, one of 8 years and another of 6. My husband was a drunkard and tortured me a lot. But by thinking about the future of children he went aboard for earning money. When he went I had given birth to a child and it was quite small. After going there my husband did not contact and he also did not send the money, due to which it was quite difficult for me to manage the house. But when I entered in Mother Group in 2065, I got support from it. By taking 100 as loan I opened a small Chatpate shop and I was quite confident after getting the training that helped me in my business. Furthermore, by the help of Mother Group I got a job of a cleaner in Miteri Bank. By these all, I have become able to provide the education to my children.

\section{Conclusion}

Mothers groups have played vital role for women empowerment and developing social development. Hanshposha mothers group had launched programs such as literacy advocacy, organizational skill enhancement training, vocational training, tailoring, leadership training, beautician training etc focusing on mother's inner as well as their organizational capability 
enhancement, productivity, efficiency, social awareness and economic upliftment, which plays the vital role in their empowerment. The researcher has found various changes on mother's status and attitude after involvement in MG, MG programs change the mother's various aspect like decision making, skill development, economic independence, increase in mobility, change in social, political and psychological situation. MG has provided platform to mothers for exercising organizational norms, values and skills which has enhanced their level of confidence to deal with other people. As a result, 70 percent mothers have felt positive change in the attitude of family members towards them after their involvement in MG. And 33 percent mothers have felt positive change in the attitude of the neighbors towards them.

Mothers Group of Hanshposha has contributed much in social development like cleaning trails, making road, plantation on public area, financial support to local school, and construction of building for temples, financial support to helpless people and poor people and maintaining peace and harmony in the community. They have initiated door-to-door campaign for making local people aware of good sanitation around home and making toilet. As a result, nearly 90 percent of the toiletless family built temporary toilets. There is increment of self motivated women's participation in various social institution like school management committee, drinking water supply management committee, forest users group, road construction committee, temple construction committee etc. Saving and credit groups were organized to increase the scope of income generating activities and help women gain access to family credit.

MG members are facing various problems like internal dispute among members, lack of creativity and innovative activities in the group, frequent influence over the group by the few dominant mothers, lack of sufficient guidance from social leaders, lack of networking with other women related organization, lack of sufficient financial resource, lack of education, interMG networking and low level of self encouragement of the mothers because of lack of family members encouragement to get involved in mothers group.

\section{References}

Batliwala, S. (1993). Empowerment of Women in South Asia: Concepts and Practices. AsianSouth Pacific Bureau of Adult Education.

Batliwala, S. (1994). Women's Empowerment in South Asia: Concepts and Practices FAO/FFHC.

Batliwala, S. (2007). Taking the power out of empowerment: an experiential account. Development in Practice 17(4/5): 557-65.

Central Bureau of Statistic. (2011). Statistical Report of Population Census 2011. Government of Nepal. 
Cornwall A., Eade D. (2011). Deconstructing Development Discourse: Buzzwords and Fuzzwords. Practical Action Publishing.

Cornwall, A. (2016). Women's Empowerment: What works? Journal of International Development J. Int. Dev. 28, 342-359.

Government of Nepal. (2008). Constituent assembly secretariat. Government of Nepal.

Government of Nepal. (2015). Constitution of Nepal. Government of Nepal

Gurung, K. (1998). Samaj-Seva ra Grameen Bikashma Ama Samuha Ko Bhumika, (Unpublished Master's Thesis, Tribhuvan University).

Kabeer, N. (1999). Resources, agency, achievements: reflections on the measurement of women's empowerment. Development and Change.

Megharaja, B. (2014). Women empowerment: A challenge of $21^{\text {st }}$ century. International Journal of Management, it and Engineering, 4(2), 78-92.

Narang, U. (2012). Self help group: An effective approach to women empowerment in India. International Journal of Social Science and Interdisciplinary Research, 1(8), 1-7.

Pandey, B. (2019). Women in Nepali Politics. Adarsha Books.

Rowlands. (1997). Questioning Empowerment: Working with Women in Honduras. Oxfam Publishing.

Sharma, J. (1997). Evolution of Traditional/Indigenous Institutions and Their Relevance in Development Co-operation: A Study of Mothers' Groups in Parbat District. Institute for Integrated Development Studies. 